ISSN 2518-1521 (Online), ISSN 2226-2830 (Print) ВІСНИК МАРІУПОЛЬСЬКОГО ДЕРЖАВНОГО УНІВЕРСИТЕТУ СЕРІЯ: ІСТОРІЯ. ПОЛІТОЛОГІЯ, 2020, ВИП. 28-29

The course of the negotiations between Britain and the European Union on the conditions of the country's exit from the organization is considered. This process was most complicated by the Northern Irish factor and led to a political crisis in the United Kingdom. The Brexit agreement was only ratified on the fifth attempt after the snap parliamentary elections.

The article considers the pros and cons of the final decision to establish a «mixed» border between states, that is conducting border checks not between Northern Ireland and the Republic of Ireland, but between Northern Ireland and other territories of the United Kingdom. The authors conclude that this solution, on the one hand, is conducive to further maintaining peace in the region, but on the other hand, reduces Northern Ireland's ties with the United Kingdom and increases it with the Republic of Ireland. In the long run, this may lead to the exercise of the right to hold a referendum on the union of Northern Ireland with the Republic of Ireland, as provided for in the Belfast Agreement.

Keywords: Brexit, United Kingdom, Northern Ireland, Republic of Ireland, border, separatism.

УДК 327(410):314.15-026.48”2000/2010”

\title{
Ie. Blazhevska
}

\section{EVOLUTION OF THE UNITED KINGDOM IMMIGRATION POLICY IN THE EARLY 2000'S}

This article provides a comprehensive overview of Britain's immigration policy early 2000 's. Britain was once known as a country of 'zero immigration' and given that the majority of Britain's post-war restrictive measures were targeted at non-white immigrants, many scholars contend that Britain's immigration regime was underpinned by a racialized discourse. In stark contrast to Britain's past record, the Labour governments of 1997 to 2010 pursued an expansionary economic immigration policy. The chapter builds a narrative of British immigration policy until 2010 and serves to demonstrate the unprecedented shift under the Labour governments in comparison to Britain's post-war restrictive framing.

Keywords: immigration policy, the Labour government, Great Britain.

DOI 10.34079/2226-2830-2020-10-28-29-161-167

Recent theoretical developments have revealed that the United Kingdom has become known for its zero-immigration policy stance with the goal of limiting immigration to zero or near zero. In other words, "control" - keeping out unwanted migrants - historically has been the policy position of the United Kingdom.

Since January 2002, however, with the introduction of the Highly Skilled Migrants Programme, the piloting of the points system, there has been an overturning of the once traditional immigration position. The rhetoric of "controlling" immigration has now become "managing" immigration and the unrealistic goal of zero immigration has been changed to letting in those who will make a contribution to the UK economy. The HSMP was the United Kingdom's pilot experience with a points based immigration system. Later, in 2008, the Australian-style points based system, as the Home Office calls it, was implemented to overhaul the existing instruments 
ISSN 2518-1521 (Online), ISSN 2226-2830 (Print)

ВІСНИК МАРІУПОЛЬСЬКОГО ДЕРЖАВНОГО УНІВЕРСИТЕТУ

СЕРІЯ: ІСТОРІЯ. ПОЛІТОЛОГІЯ, 2020, ВИП. 28-29

for economic migration into the United Kingdom. This shift is significant since it meant a change from the existing employer- led system under the work permit system to a government- led system. It also marked a notable liberalization of British labor immigration policy as high- skilled migrants gain relatively unhindered access to the British labor market (Home Office, 2002c, p.1).

There is a long history of UK immigration policy highlighting a change of emphasis in immigration policy in political, social, economic, history and philosophy sciences. UK immigration policy is a well-recognized issue which necessitates a better approach. Traditionally, the United Kingdom's immigration policy emphasized keeping intake numbers low, as close to zero as possible (Home Office, 2002d). While today the emphasis is not about keeping numbers low, it is still about keeping out "undesirables." Britain was historically a country of emigration until World War II when that trend reversed as immigrants came to outnumber emigrants. The increase in intake was a result of labor shortages experienced during the early postwar years with many immigrants originating from the "New Commonwealth," consisting of the Caribbean, India, and African colonies. Because of labour shortages and stiff competition from its European neighbors in recruiting southern European immigrants, the British encouraged immigration from the New Commonwealth. In 1948, the British Nationality Act gave these colonial subjects and former colonial subjects' freedom of movement and all the rights and privileges as British citizens (Layton-Henry, 1992, p.298).

However, the upsurge of immigrants from the former colonies stimulated concerns about restricting immigration, particularly of nonwhites. Subsequently, immigration policy was changed to keep out these so-called unwanted migrants and to keep immigration at low levels. Britain "display[ed] an exceptionally strong and unrelenting hand in bringing immigration down to the 'inescapable minimum, (Layton-Henry, 1992, p.331)" with policies aimed at revoking citizenship privileges from subjects of its former colonial empire. Government officials justified such a policy stance on maintaining good race relations within the country. In the midst of high anti- immigrant sentiment and strong public opinion supporting restricting immigration, particularly of non-whites, the Commonwealth Immigrants Act closed the door for new Commonwealth subjects to the United Kingdom in 1962 by requiring entry vouchers from the Ministry of Labour for everyone but British passport holders. Immigrants were granted vouchers if they had either a job offer or highly demanded shortage skills. With the passage of time and persistent public discontent, restrictions on economic migration into the United Kingdom became even tighter. In 1965, the government added a quota to the regulations, permitting only 8,500 vouchers per year to New Commonwealth citizens (Clarke and Salt, 2003, p.563). By this time, immigrants without blood ties could only enter the United Kingdom through the work permit system and were not permitted family reunification or permanent residence. Workers were intended to be temporary. The Immigration Act and Rules, which came into force in 1973 - the same year the United Kingdom became a member of the European Community (Clarke and Salt, 2003, p.566), - regulated immigrants, thereby requiring a work permit to gain entry. It is the basic framework that governs the regulation of entry, all categories of removals (deportations), visit, family reunion, and asylum. The Immigration Rules were altered in subsequent years. Since undergoing at least fifty ad hoc changes, the rules comprise more than eighty different routes of entry into the United Kingdom. The work permit scheme - the route through economic migrants enter the United Kingdom - was entirely demand led, and, as such, individuals were granted work permits only at the request of employers. To satisfy labor market tests, employers had to show that there was no suitable British native to do the job before a work permit was granted. Though work permits were available only for positions 
ISSN 2518-1521 (Online), ISSN 2226-2830 (Print)

requiring high skills - the rationale being that training a native is unfeasible - there were no quotas or caps on numbers of immigrants.

By the late 1980s, it became evident that the work permit scheme had to be altered to give more mobility and flexibility in the domestic labor market because of skills shortages resulting from inadequate public spending on education and increased global mobility (Clarke and Salt, 2003, p.572). In 1991, the government made changes to the work permit scheme, which "was seen as imposing barriers and costs on some companies for which it was advantageous to employ foreign labour" (Clarke and Salt, 2003, p.565).

The changes included prioritizing approvals of work permits, giving preference to highskilled migrants in managerial and shortage occupations, and making it easier for intracompany overseas transfers. Further relaxation of the controls surrounding the work permit occurred in 2000, making it, as former Immigration Minister Barbara Roche described, "more employer- friendly and much easier to administer" (Home Office, 2002b). The Department for Education and Employment "enabled it to deal with some shortages that have been experienced in certain sectors" (Home Office, 2002c). As of October 2000, migrants with intermediate skills and graduates with little experience were eligible for a work permit. The changes also made it less onerous to renew permits and extended the duration of stay to five years instead of four. The turnaround time for processing applications also improved, permitting 90 percent of applicants within 24 hours (Somerville, 2007, p.2). Two years later, in 2002, the government further liberalized immigration controls for highskilled migrants with the introduction of the Highly Skilled Migrants Programme.

Through the HSMP, admissions barriers were reduced even further for high- skilled migrants such that they could enter without a job offer, as required by the work permit system. In 2005, Home Secretary Charles Clarke continued the trend of his predecessors to reform Britain's immigration controls by overhauling the entire immigration system and basing all routes of entry into the United Kingdom (except for family reunion and asylum streams) on a points scale. Under this system, points are designed to evaluate attributes, such as earning potential and success and, most interestingly, to determine one's proclivity to adhere to immigration rules and conditions governing their stay.

Since problem of UK political landscape in solving immigration issues can have serious consequences, it is imperative to better understand the push and pull factors of its establishing. The political climate for immigration reform was ripe with the victory and parliamentary majority of New Labour in 1997 and again in 2001 (Layton-Henry, 1992). The Blair administration was instrumental in changing the face of British immigration (Layton-Henry, 2004). Previous administrations' concerns about skills shortages and the international competition for skills - as reflected in changes to the work permit system since 1991 - which continued through the turn of the century, were aggressively addressed by the Labour government. Skills shortages gave impetus for the change in position. This is made clear in the government's response to the Home Affairs Committee First Report, 3 in which it acknowledges "that certain employment sectors suffer acute shortages and has accordingly simplified the process for employers seeking to recruit foreign nationals for such jobs" (Home Office, 2002a). Bringing in foreign workers to fill these gaps in the labor market is an immediate, though temporary, solution to increasing the supply of professionals in the medical or other fields.

In the healthcare, banking, and information technology sectors, employers complained about skills shortages. Vacancies were apparent in jobs requiring both high and low skills. In talking about labor shortages, a policy analyst noted that the problem is pervasive. He remarked, "It's every single area. There were low skilled jobs, high skill jobs. There are still actually. The number of 
vacancies is still very high. Labor shortages in education and health care further prompted Labour's favorable disposition to immigration (Layton-Henry, 1992, p.300). An immigration expert stated, "How do you increase the supply of doctors and nurses, which is relatively inelastic because it takes a lot of training? Well you do that by bringing people from overseas." The United Kingdom, unlike its European counterparts, answered calls from employers to be able to tap into the global market (Somerville, 2007).

The Leitch report confirmed this concern. It revealed that Britain is uncompetitive because of its inadequate skills base - the major weakness separating the productivity of the United Kingdom from its global competitors. Consequently, the objective of the government was to become a global leader in skills by 2020 (Smith, 2009). Immigration is complementary to the government's offensive strategy of building its skills base. The mismatch and lack of the skills in the labor market gives incentive to recruit foreign labor even if employers may prefer domestic labor with the appropriate training. As a policy analyst remarked employers would rather have British workers because it is a bit more of a hassle to bring people in from outside because you have to go through a work permit system, the employers would probably rather that British people have the skills here first, just because they're here and it's much easier for them to do it. In 2002, the United Kingdom was ranked as having the second largest skills shortage in Europe (Home Office, 1998). The extent of shortages in the IT sector is caricatured by the desperation by Ridgeway, a multimedia company, as reported by the BBC that "offered $£ 1,000$ to any member of the public who can suggest a suitable employee." The severity of the skills shortage was such that it was described as handicapping the economy (Home Office, 2002a).

The home secretary, David Blunkett, echoed this need for fundamental overhaul in the language and subsequent policy regarding immigration into the United Kingdom. "Migration," he acknowledged, "is an inevitable reality of the modern world and it brings significant benefits" (Home Office, 2002a). The "modern world" to which he refers is marked by access to telecommunications and ease of travel that facilitates the heightened movement of people across the world. In other words, the government recognized globalization as playing an important role in immigration and actively formulated policies accordingly (Layton-Henry, 2004). The increase in the number of international migrants translates into more migrants seeking to cross borders. Tight restrictions on entry routes for economic migrants meant determined migrants attempt to enter under false pretenses, such as asylum seekers, or do so clandestinely. In light of this, the white paper Secure Borders, Safe Haven: Integration with Diversity in Modern Britain was "intended to refocus the agenda onto the wider issues of migration: on the global reality of increasing international mobility" (Home Office, 2002a, p.22).

Besides skills shortages, within the government and the public, a growing concern emerged regarding immigration abuses among migrants feigning asylum to gain admission into the United Kingdom. Outside of family reunification, immigration for work was limited to work permits acquired through employer sponsorship. Because of this encumbrance, David Blunkett and the Home Office believed there were "bogus" asylum applications as economic migrants sought entry via this route. Opening up economic migration, the argument follows, would reduce the number of asylum applications and re-establish the government's ability to manage immigration. The general feeling was that, on the one hand, the large number of vacancies and tight controls preventing migrants from filling positions encouraged illegal immigration and false asylum claims. The Home Affairs Committee's First Report for the 2000 - 2001 session notes that vacancies are a pull factor for economic migrants, who, because of tight controls, disguised themselves as asylum seekers. On the other hand, making entry harder for illegal immigrants and asylum seekers (genuine or bogus) 
ISSN 2518-1521 (Online), ISSN 2226-2830 (Print) ВІСНИК МАРІУПОЛЬСЬКОГО ДЕРЖАВНОГО УНІВЕРСИТЕТУ СЕРІЯ: ІСТОРІЯ. ПОЛІТОЛОГІЯ, 2020, ВИП. 28-29

translates into cutting off supplies of labor needed in various sectors (Somerville, 2007, p.348). According to Blunkett, "we knew if you didn't have very substantial legal routes for working in this country our economy would be closed down" (Somerville, 2007, p.350). This period marked a revolution in the conceptualization and attitude toward immigration in the United Kingdom.

Before membership in the European Union of the Accession 8 (A8) in the 1990's, the growth in the number of asylum seekers played an important role in the increase of immigration inflows. The large numbers of asylum seekers entering the country intensified the debate surrounding immigration (Hansen, 2000). As such, asylum dominated the debate at the expense of a broad conversation about immigration thereby tainting the public's perception. The distinction between migration for work and for asylum seekers was lost in the media and, by extension, the public debate.

One public opinion poll, conducted by in 2002, found that the large majority of the public felt that the media described asylum seekers and refugees with negative words - "illegal immigrant" and "desperate" were among the top three - when asked about the terminology most often associated with asylum seekers and refugees (Home Office, 2005). Public opinion polls also revealed the public's waning confidence in the government's ability to control immigration. A February 2003 poll showed that 85 percent of the public disagreed that the government had control over immigration. Similarly, a corresponding 76 percent of Britons disagreed that the government is "open and honest about the scale of immigration" to the country. Two-thirds wanted tougher immigration laws and 72 percent were dissatisfied with "the way the government is dealing with immigration and asylum" (Harper, 2013).

The relaxation of immigration controls for international workers is a new position on immigration as historically administrations tightened controls on nonwhite migration in response to public sentiment (Home Office, 2002d), when it comes to immigration in the United Kingdom, "[policymakers"] demiurge is not the receivers of concentrated benefits, such as employers or ethnically groups, but the bearers of diffuse costs: a public that has been overwhelmingly and immovably hostile to ... immigration" (Hansen, 1999, p.809). Under the Thatcher administration, strict controls against nonwhite immigrants were considered good for race relations (Spencer, 2002).

The most significant observation of this study is the fact that the United Kingdom is an interesting case to delve into the problem of migration paradox. As noted earlier, scholars present the migration paradox confronting states as import labour to boost the economy and at the same time satisfy the public's demand for restrictive policies. To circumvent this dilemma, states opt for the former and are ambivalent about the latter. In the United Kingdom, public objection to immigration - be it non-white, humanitarian, or illegal - has been a constant feature of the political landscape. The United Kingdom is not unlike any other non-traditional immigration countries in this respect. However, in the United Kingdom, public outrage is particularly high, and it historically tended to direct policy on and certainly rhetoric surrounding immigration, perhaps more so than employers do.

\section{Conclusions}

Broadly translated our findings indicate that to quell public concerns, in the United Kingdom, immigration has traditionally been framed in terms of denying entry to unwanted migrants. The goals of "reforms is to admit people selectively in order to maximize the economic benefit of migration to the UK" and "to build a system that will be more responsive to economic need, simpler and more robust against abuse" (Home Office, 2002c). A mantra that has come out of the Home Office expressed over the years is "letting in those that Britain wants [immigrants that will make a 
ISSN 2518-1521 (Online), ISSN 2226-2830 (Print)

ВІСНИК МАРІУПОЛЬСЬКОГО ДЕРЖАВНОГО УНІВЕРСИТЕТУ

СЕРІЯ: ІСТОРІЯ. ПОЛІТОЛОГІЯ, 2020, ВИП. 28-29

positive economic contribution to society] and keeping out the unwanted." Particularly in the 1990's, the media's portrayal of asylum seekers confounded the immigration issue and muddied all discussions about other streams of immigration into the United Kingdom. The paper concludes by arguing the government is always on the defensive, making policies or promoting rhetoric that represents the government as tough. Layton- Henry (Layton-Henry, 1992, p.331) observes, "Tough rhetoric is often used to distract attention from sensible liberal policies that politicians fear will be criticized in the popular press." The rhetoric surrounding the introduction of the HSMP in 2002 and the PBS in 2005 is that of fixing the asylum morass and stopping abuses to the system. To confront and dispel this public notion of mismanagement, officials chose a system that allows for transparency into the type of immigrants selected and the needs they fulfill. The PBS system gives a sense of government control. Points systems are state planned (although there can be consultations with stakeholders) and the system puts the decision of who and how many entirely in the hands of government. Insofar as control is stressed, it suggests that the government is attentive to the restrictionist preferences of the average member of the public to a certain degree. In the United Kingdom, politicians are beholden to the public with respect to immigration policy (Somerville, 2007).

In addition, these findings provide additional information about high-skilled migrants to be offered permanent residence and not required to have a job offer. Thus, when looking at economic immigration, one finds a divergence from average public preferences for closing the valve to immigration (limited to no immigration). Labour adopted an expansive policy to recruit highly skilled immigrants, so liberal that there was no cap set on the number of highly skilled immigrants allowed to enter.

Importantly, our findings provide evidence for a repackaging of the public's concern in the UK: it is not that the public wants zero migration; rather they want managed migration. The authorities frame the public's fear in terms of their concern for abuse of the system, a clever strategy that shifts the public's attention from numbers to an issue of management. To confront and dispel this public notion, officials chose a system that allows for transparency into the type of immigrants selected and the needs they fulfill. Permitting highly skilled (or even skilled migrants) accomplishes this. As noted publicly by the Home Office migrants tend to be more qualified and contribute more to the British economy than native labour. Such evidence thus makes it easier for public acceptance (better public perception) of migration.

\section{References}

Clarke, J. and Salt, J., 2003. Work Permits and Foreign Labour in the UK: A Statistical Review. Labour Market Trends, 111(11), 563-574.

Hansen, R., 1999. The Kenyan Asians, British Politics, and the Commonwealth Immigrants Act, 1968. The Historical Journal, 42(03), 809-834.

Hansen, R., 2000. Citizenship and Immigration in Post-war Britain. Oxford: Oxford University Press.

Harper, M., 2013. Written Ministerial Statement on the Seasonal Agricultural Workers Scheme and the Food Processing Sectors Based Scheme. GOV.UK, [online] September 12. Available at: <https://www.gov.uk/government/speeches/seasonal-agricultural-workersscheme-and-the-food-processing-sectors-based-scheme> (Accessed 20 September 2020).

Home Office, 1998. Fairer, Faster, Firmer-A Modern Approach to Immigration and Asylum. London: Home Office. 
ISSN 2518-1521 (Online), ISSN 2226-2830 (Print) ВІСНИК МАРІУПОЛЬСЬКОГО ДЕРЖАВНОГО УНІВЕРСИТЕТУ СЕРІЯ: ІСТОРІЯ. ПОЛІТОЛОГІЯ, 2020, ВИП. 28-29

Home Office, 2002a. Secure Borders, Safe Havens - Integration with Diversity in Modern Britain. London: Home Office.

Home Office, 2002b. Highly Skilled Migrants Programme. London: Home Office.

Home Office, 2002c. Working Holidaymakers Scheme: Consultation Documents. London: Home Office.

Home Office, 2002d. Knowledge Migrants: The Motivations and Experiences of Professionals in the UK on Work Permits. London: Home Office.

Home Office, 2005. Controlling Our Borders: Making Migration Work for Britain - Five Year Strategy for Asylum and Immigration. London: Home Office.

Layton-Henry, Z., 1992. The Politics of Immigration: immigration, race and race relations in postwar Britain. Oxford: Blackwell.

Layton-Henry, Z., 2004. Britain: From Immigration Control to Migration Management. In: W. Cornelieus, T. Tsuda, P. Martin and J. Hollifield, Eds., 2004. Controlling Immigration. Stanford: Stanford University Press, p.297-334.

Smith, J., 2009. Migrant Workers Face Tougher Test to Work in the United Kingdom. SkillClear, [online] February22. Available at: <https://skillclear.co.uk/immigration-news/ukimmigration-news/migrant-workers-face-tougher-test-to-work-in-the-unitedkingdom/\#top> (Accessed 20 September 2020).

Somerville, W., 2007. Immigration Under New Labour. Bristol: Policy Press.

Spencer, I.R., 2002. British Immigration Policy Since 1939: The Making of Multi-Racial Britain. New York: Routledge.

Стаття надійшла до редакції 25.09.2020 p.

\section{Є. Блажевська}

\section{ЄВОЛЮЦІЯ ІММІГРАЦІЙНОЇ ПОЛІТИКИ ВЕЛИКОЇ БРИТАНІЇ У ПЕРШІЙ} ДЕКАДІ 2000-х.

У иүій статті подано огляд іммігращійної політики Великої Британії у першій декаді 2000-х. Упродовж тривалого часу Британія була відома як країна «нульової імміграції» та враховуючи, щуо більшість повоєнних обмежувальних заходів у Великій Британії були спрямовані на іммігрантів, які були расово відмінними від корінних жителів Британських островів. Расистський дискурс імміграчійної політики Великої Британії визначав форми та методи ї̈ реалізації. На відміну від минулих запитів Великої Британії, лейбористські уряди 1997-2010 років проводили експансивну економічну імміграційну політику.

У статті аналізується імміграційна політика Великої Британії як демонстрація безпрецедентної трансформації політики уряду лейбористів порівняно з повоєнними рестрикиійними заходами.

Ключові слова: імміграційна політика, уряд лейбористів, Велика Британія. 